\title{
MED BØNNEN SOM VÅBEN
}

Politisk konflikt og flertydigt religiøst engagement i Tyrkiet

\author{
IDA HARTMANN
}

„Løgne og falske anklager er deres våben,“ siger Nuriye og aer roligt katten, der har rullet sig sammen i hendes skød. „Men vores sti er ikke belagt med vold og magtmisbrug. Vores bønner er vores stærkeste våben mod dem og deres undertrykkelse." ${ }^{\text {FI }}$ Fra Nuriyes lille kvistkøkken kan man se ud over Istanbuls tage. Nuriye er midt i 40'erne og journalist. Hun er også en central person i Hizmet, en indflydelsesrig sunnimuslimsk bevægelse, hvis frontfigur er den kontroversielle tyrkiske prædikant Fethullah Gülen. Året er 2015. En dramatisk magtkamp raser mellem Gülen og landets præsident, Recep Tayyip Erdoğan, der ellers tidligere fandt fælles fodslag i ambitionen om et Tyrkiet mere solidt forankret i sunniislamisk tradition. Året efter vil konflikten kulminere i et blodigt kupforsøg, som Gülen anklages for at stå bag. Det bliver enden på Hizmet-bevægelsens indflydelse i Tyrkiet og fører til, at Nuriye, ligesom tusindvis af Gülens tilhængere, forlader landet i hast. Men dér er vi ikke endnu. Udgangen på konflikten er stadig uvis. Magtkampen undergraver Hizmet. Skoler, mediehuse og firmaer med forbindelser til bevægelsen lukkes, og Gülens sympatisører stemples som landsforrædere og terrorister. Nogle fængsles, mange mister deres job, de fleste oplever naboer, venner og familiemedlemmer vende dem ryggen i sympati med Erdoğan. Men også Erdoğan og hans Retfærdigheds- og Udviklingsparti (Adalet ve Kalkınma Partisi, AKP) er svækket. Korruptionsanklager, økonomisk tilbagegang og voksende utilfredshed underminerer præsidentens og partiets magt. I denne artikel undersøger jeg, hvordan bønnen var et „våben“ for Nuriye og mine andre Hizmet-bekendte i konflikten mellem Hizmet og AKP. Hvordan bad folk under konflikten? Hvilken virkning forventede de af deres bønner? Forandrede konflikten deres forhold til bøn? Og hvad fortæller det os om, hvilken rolle religiøst engagement spiller i en situation præget af opbrud, uvished og afmagt?

For Nuriye henviser „bøn“ til en række forskellige praksisser: de fem daglige bønner (namaz på Tyrkisk, şalât på arabisk), recitation af Koranen eller af Allahs 
navne (zikir), oplæsning af historiske bønner samt mere personlige og improviserede bønner $(d u a)$. Antropologiske studier af islamisk bøn har primært fokuseret på de fem foreskrevne bønner, kendetegnet ved streng kropslig koreografi og rytmisk gentagelse over tid. ${ }^{2}$ Nogle har fremhævet den daglige bøn som et middel til at kultivere et fromt Selv (Mahmood 2001; Haeri 2013) og indskrive sig i et islamisk fællesskab (Henkel 2005). Andre beskriver, hvordan den foreskrevne bøn kolliderer med ikke-religiøse interesser og forpligtigelser og kan medføre moralsk splittelse (Simon 2009; Debevec 2012). Fælles for disse ellers forskellige studier er, at de primært beskriver den daglige bøn som en teknik, hvorigennem den bedende (med svingende succes) handler på sig selv (jf. Mittermaier 2012). Nuriye fremhævede også ofte bønnen som en indadvendt praksis, der „løsnede hjertets knuder“ og „åbnede sjælens porte mod Gud““. Men hendes beskrivelse af bønnen som et våben peger også på en anden, mere udadvendt dimension: at bønnen ikke udelukkende gør noget ved Selvet, men også potentielt ved verden. Min interesse her er derfor forholdet mellem bønnens indadvendte og udadvendte dimension, mellem bønnen som teknik til at forbedre Selvet og som metode til at forandre verden. En hovedpointe er, at forholdet mellem disse to modaliteter ændres, i takt med at Tyrkiets politiske landskab forandres, og mine informanters handlerum snævrer ind. Artiklen kan således læses som en etnografisk udforskning af, hvad Marcel Mauss i sit tidlige, men længe oversete studie af bøn kalder bønnens „uendelige smidighed“- dens evne til at „,varetage de mest forskelligartede funktioner ... men uden dog at forandre sig“" (Mauss 2003:22). Jeg lægger op til, at det netop er i kraft af bønnens smidighed eller flertydighed, at bønnen fungerede som et „våben“ $i$ konflikten. Bønnens forskellige modaliteter gjorde det muligt for mine bekendte $\mathrm{i}$ Hizmet at veksle mellem forskellige måder at forstå og forvalte konflikten på og dermed tilpasse sig et politisk landskab under dramatisk forandring.

Ved at fremhæve bønnens flertydighed og dennes relation til en specifik politisk kontekst bidrager artiklen til den antropologiske samtale om, hvad islamisk engagement er og gør. I sit paradigmatiske studie af en egyptisk fromhedsbevægelse fokuserer Saba Mahmood (2012 [2005]) på islamisk engagement som en række selvdisciplinerende teknikker med det primære formål at kultivere et fromt Selv. Mahmoods tilgang har fået stor indflydelse, dels fordi hun identificerer praksis som forudsætning for tro, og dels fordi hun på baggrund af sin etnografi udfordrer en række sekulære, liberale antagelser om subjektivitet, handlekraft og frihed. Men Mahmoods fokus på selvkultivering er også blevet kritiseret for at være for snævert. Nogle påpeger, at selvkultivering kun er én dimension af et islamisk engagement, som for mange muslimer også - og måske i højere grad - består i at underkaste sig guddommelige kræfter, der er både uforudsigelige og hinsides menneskelig kontrol (Mittermaier 2012; Rytter 2016). Andre kritise- 
rer litteraturen om selvkultivering for at portrættere islamisk engagement som altgennemsyrende og dermed underspille, at for mange muslimer er religiøsitet blot en blandt mange, ofte konkurrerende, komponenter i en mangfoldig hverdag (Schielke 2009; Soares \& Osella 2009). Lidt forenklet peger kritikken altså på, at islam handler om mere end selvkultivering, og at muslimers liv handler om mere end islam. Med bønnen som etnografisk omdrejningspunkt bidrager denne artikel til debatten ved at vise, at for mine bekendte i Hizmet er islamisk engagement indadtil flertydigt og udadtil i dynamisk dialog med en omskiftelig politisk virkelighed. Mere specifikt udfolder artiklen, hvordan forskellige dimensioner af det islamiske engagement henholdsvis trækkes i forgrunden eller skubbes i baggrunden, $\mathrm{i}$ takt med at den politiske konflikt eskalerer.

I artiklen fungerer ,handlekraft" som den analytiske prisme, der fremkalder bønnens forskellige modaliteter. Også her trækker jeg på den igangværende debat inden for antropologien om islam. I Mahmoods analyse består handlekraft som udgangspunkt $i$ at underkaste sig islamiske normer og forme Selvet i overensstemmelse med disse. I modsætning hertil påpeger Amira Mittermaier (2012), at hendes informanter lokaliserer den primære handlekraft hos Gud, hvorfor menneskelig handlekraft reduceres til evnen til at respondere på det uforudsigelige og ukontrollable. I begge tilfælde defineres menneskelig handlekraft som ,præsubjektiv“, altså ikke som noget, mennesket i første omgang besidder, men som noget, der tilegnes gennem islam, enten som doktrin eller som guddommelig kraft. Heroverfor fokuserer nyere studier på en form for handlekraft, der mere entydigt udspringer fra subjektet, fx gennem analyser af, hvordan muslimer forsøger at forhandle og måske endda forandre den skæbne, de er tildelt af Gud (Elliot \& Menin 2018). I denne artikel viser jeg, at bønnen rummer alle tre former for handlekraft - handling som respons på det ukontrollerbare, handling som en metode til at bearbejde Selvet og handling som et forsøg på at forme og forandre skæbnen - individets såvel som nationens. Jeg peger på, at for mine informanter er disse forskellige modaliteter ikke modsætninger, men hinandens forudsætninger, og at deres indbyrdes forhold skifter, i takt med at det omkringliggende politiske landskab ændrer sig.

Artiklen bygger på 12 måneders feltarbejde i Istanbul i 2015, udført primært blandt akademikere, civilsamfundsaktivister og husmødre, der var aktive i Hizmetbevægelsens dengang vidtforgrenede netværk af uddannelsesinstitutioner, mediehuse, firmaer og foreninger (Yavuz 2013). Formålet med artiklen er at undersøge, hvad nogle af mine informanters tilgang til konflikten fortæller os om bøn. Den skal således ikke læses som en generel repræsentation af Hizmet, en på daværende tidspunkt vildtvoksende, mangfoldig og løst forbundet bevægelse. Artiklen kan dog godt læses som et bidrag til den litteratur om Hizmet, der ud- 
kom i kølvandet på kupforsøget. I en antologi med titlen Turkey's July 15th Coup. What Happened and Why fordømmer en række toneangivende forskere bevægelsen som en „magtbegærlig struktur“ (Yavuz 2018). Selvom det er sandsynliggjort, at visse fraktioner i Hizmet har været villige til at strække sig langt for politisk indflydelse (jf. Jenkins 2009), er det vigtigt at holde fast $i$, at det ikke er endeligt bevist, at folk fra bevægelsen var involveret i kupforsøget. Men desuagtet spørgsmålet om ansvar for det fejlslagne kup er fremstillingen af Hizmet som en „magtbegærlig struktur“ problematisk, fordi den underspiller bevægelsens mangfoldighed og mistænkeliggør de hundredtusinder af tyrkiske borger, der identificerede sig selv med Hizmet, men befandt sig fjernt fra det storpolitiske spil. Ved at zoome ind på en håndfuld af disse borgere søger artiklen at nuancere repræsentationen af Hizmet.

Første del af artiklen beskriver, hvordan nogle af mine bekendte i bevægelsen brugte bønnen til at påkalde sig Guds intervention i den politiske konflikt. Anden del viser, hvordan mine informanter redefinerede konflikten som en „test“, hvormed Gud påkaldte dem at forbedre deres Selv, i takt med at deres situation forværredes. Afslutningsvis diskuterer jeg, hvordan bønnen besidder en evne til at mediere mellem forskellige former for handlekraft og dermed giver dem mulighed for at forholde sig smidigt til et omskifteligt politisk landskab. Men først vil jeg kort opridse konturerne af det politiske drama, der danner baggrund for de bønspraksisser, artiklen beskriver.

\section{Et „vi, der krakelerede“}

Med jordskredssejren i 2002 bliver AKP det første parti med rødder i politisk islam, der danner flertalsregering i Tyrkiet. Udfordret af militæret, der betragter sig selv som den sekulære republiks vogter og historisk har afsat regeringer, der blev fundet for eftergivende over for islam, danner AKP en uofficiel alliance med Hizmet. På daværende tidspunkt er Hizmet allerede en indflydelsesrig aktør i civilsamfundet, forretningslivet og medielandsskabet, men vigtigere er det måske, at nogle af Gülens sympatisører er centralt placeret i retsvæsnet, politiet og uddannelsesinstitutionerne, der ellers er domineret af selvidentificerede sekularister (Yavuz 2013; Turam 2007). I de følgende år lykkes det AKP-Hizmet-alliancen at svække militæret og overtage kontrollen med centrale statsinstitutioner (Jenkins 2009). Men så snart regeringsmagten er sikret, vender de to alliancepartnere sig mod hinanden i en strid om, hvordan magten skal fordeles. Konflikten udspiller sig gennem højtprofilerede korruptionsskandaler og dramatiske politiaktioner, men den trækker også dybe spor i almindelige tyrkeres hverdagsliv, ikke mindst fordi det er første gang i Tyrkiets historie, at den dominerende politiske brudflade 
ikke er mellem sekularister og praktiserende muslimer, men internt i den sidste gruppe. ,Aldrig havde jeg troet, at folk, der også beder og bærer tørklæde, skulle stikke os i ryggen," kommenterer en af mine bekendte i Hizmet, Merve, da en nabokvinde demonstrativt passerer os på gaden uden at hilse. Det var et intimt og fortroligt „vi, der krakelerede“, siger Lale, med henvisning til den splid, konflikten såede internt blandt religiøst konservative civilsamfundsorganisationer, der sympatiserede med henholdsvis AKP og Hizmet.

Det „vi“, Lale refererer til, har rødder i den islamiske vækkelsesbølge i Tyrkiet, der ligesom andre steder i verden genererer momentum fra slutningen af det 20. århundrede (Eickelman \& Piscatori 1996; Hirschkind 2006; Yavuz 2003). I Tyrkiet er bevægelsen i høj grad en reaktion på det sekulære projekt, der har forvist praktiserende muslimer til samfundets geografiske, økonomiske og politiske periferi siden republikkens fødsel i 1923. Godt nok koblede republikkens politiske arkitekter det at være tyrker med det at være muslim i et forsøg på at fremmane en forenet nation fra ruinerne af det osmanniske imperium, karakteriseret ved vildtvoksende etnisk, religiøs og sproglig mangfoldighed (Cagaptay 2006). Men samtidig ønskede den politiske elite at distancere den nye republik fra det faldne osmannerrige og indskrive den som en del af det moderne, sekulære Europa. Derfor gennemførte de vidtrækkende reformer, der skulle fortrænge synlig islamisk praksis fra det offentlige liv og ind i privatsfæren (Zürcher 1998:180-81). Det medførte systemisk marginalisering af landets religiøse borgere.

Denne politiske geografi ændres i slutningen af det 20. århundrede, hvor en række politiske og økonomiske reformer danner grundlag for fremkomsten af en praktiserende muslimsk middelklasse (White 2013:35-38). Med voksende selvtillid kræver religiøst konservative aktører nu deres ret til at deltage i det offentlige liv uden at gå på kompromis med deres religiøsitet. Nogle har beskrevet denne islamiske vækkelsesbevægelse som et identitetspolitisk projekt (Göle 1996). Andre placerer dens rødder i økonomisk liberalisering og øget kommercialisering (Navaro-Yashin 2002). Heiko Henkel (2005) påpeger dog, at sådanne studier undervurderer, hvor vigtig religiøsitet og i særdeleshed et fælles rituelt repertoire var for at sikre bevægelsens interne sammenhængskræft. Henkel argumenterer for, at den daglige bøn ,etablerer en fast referenceramme i religiøse muslimers ellers forskellige og foranderlige livsverdner" (op.cit.488). Bønnen, med dens uforanderlige form og regelmæssige gentagelse, er således ifølge Henkel med til at skabe en fællesskabsfølelse på tværs af de forskellige og ofte modstridende fortolkninger af islam, der tegner Tyrkiets religiøse landskab. Den daglige bøn er med andre ord et vigtigt fundament for Lales , vi““. Men konflikten mellem AKP og Hizmet afslører bønnens fællesskabende effekt som knyttet til en kontekst, hvor forskellige islamiske aktører også stod i fælles opposition til den sekularis- 
tiske elite. I det øjeblik truslen fra denne fælles Anden fortoner sig, begynder det fælleskab, Henkel beskriver, også at slå revner. Denne artikel undersøger, hvilken rolle bøn spiller, når islamisk fællesskab er vendt til fjendskab.

Konkret stiller artiklen skarpt på efteråret 2015, en periode, hvor konflikten eskalerer, og magtforholdet mellem AKP og Hizmet bølger frem og tilbage. Ved valget den den 7. juni 2015 mister AKP det absolutte flertal i parlamentet for første gang i partiets historie. ${ }^{2}$ For mine informanter i Hizmet indgyder valgresultatet håb for fremtiden. Men efter en sommer med halvhjertede forsøg på at danne en koalitionsregering udskriver regeringen nyvalg. Tiden op til valget er præget af politisk turbulens, og ved nyvalget den 1. november genetablerer AKP sit absolutte flertal. Regeringen slår nu ned på personer og organisationer med forbindelser til Hizmet med fornyet kraft. Artiklen viser, hvordan dette skift i mine informanters muligheds- og handlerum afspejles i en forskydning af bønnens forestillede modtager, formål og effekt.

\section{At påkalde sig Guds intervention}

På dagen for nyvalget besøger jeg Nuriye, præsenteret $\mathrm{i}$ introduktionen, og hendes søster, Yaren, i den lille kvistlejlighed, de deler med deres kat. Nuriye er bekymret. For valgresultatet og for, om folk i Hizmet har gjort nok for at forhindre en sejr til AKP. Her tænker hun ikke på, om der er blevet stemt dørklokker, hængt valgplakater op eller arrangeret vælgermøder, men på, om folk i bevægelsen har været ihærdige nok med deres bønner. Nuriye siger:

Vi befinder os i et afgørende øjeblik. Men vi har en tendens til at stole blindt på vores Herres barmhjertighed. Og derfor lægger vi ikke det arbejde i vores bønner, som vi bør. Det er ikke nok at stole på Allahs barmhjertighed, vi skal også selv tage ansvar og gøre en indsats. Det gør vi ved at bede.

Nuriye og Yaren er ikke blinde for, at valgresultatet påvirkes af valgdeltagelse, mediedækning og eventuelt valgsnyd, men i sidste ende betragter de udfaldet, og alle andre hændelser i øvrigt, som udslag af Guds vilje. Det betyder dog ikke, at de ser sig selv som uden ansvar og indflydelse. I introduktionen til et særnummer om kristen bøn observerer Andreas Bandak, at den gængse sekulære intuition er, at bønnen er arbejdets antitese: Den arbejdende engagerer sig i verden og tager ansvar, den bedende trækker sig væk fra verden og lægger passivt ansvaret $\mathrm{i}$ hænderne på Gud (Bandak 2017:2, 5). Nuriye skelner ligeledes mellem ansvarspåtagelse og deltagelse på den ene side og ansvarsfralæggelse og distance på den anden side. Men for hende tilhører bønnen det første modus. Bønnen er arbejde. Men hvori består dette arbejde? Og hvad er dets produkt? 
I ugen op til valget overnatter jeg hos Nuriye og Yaren. De vækker mig om natten til bøn. Begge kvinder har netop afsluttet deres namaz, da jeg tager plads på det bedetæppe, de har rullet ud til mig på stuegulvet. Yaren finder nogle laminerede papirark frem og begynder at læse en bøn højt på tyrkisk. Nuriye åbner hænderne mod Gud, rokker svagt frem og tilbage og afslutter Yarens sætninger med et amin (amen). Katten gnider sig insisterende op ad Nuriyes arm, måske som reaktion på hendes grådkvalte stemme og regelmæssige snøft. Da Yaren har afsluttet bøn nummer to, lader vi hænderne glide over vores ansigter og går i seng uden yderligere snak. Næste morgen forklarer Nuriye, at Gülen har opfordret alle i bevægelsen til at underkaste sig et særligt „bønsprogram“ (dua programı) i en periode på 11 dage op til valget. Ud over de fem daglige bønner skal alle som minimum udføre en sjette natlig namaz, den såkaldte teheccüd namazl, og derefter recitere to bestemte bønner formuleret af henholdsvis Abdülkâdir Geylânî (10781168) og İmam Şâzilî (1197-1258). „Disse bønner er meget kraftfulde,“ siger Nuriye. De er fremsagt af to store sufisheiker på et tidspunkt i deres liv, hvor de hver især var udsat for forfølgelse og tyrani. „Præcis som vi er nu, “tilføjer hun. Det er bønner til Allah om, at han må „udfri os fra undertrykkelse og uretfærdighed“ $\mathrm{og}$,sikre fred og fremskridt for vores nation“. Jo flere der beder præcis disse bønner på det samme tidspunkt, jo stærkere er de, forklarer Nuriye. „Det var derfor, jeg vækkede dig,“ smiler hun skælmsk, „fordi du er gravid og derfor beder for to."

I et studie blandt muslimer på Mayotte skelner Michael Lambek mellem „tilbedende“ og „bønfaldende“ bønspraksisser, hvor de sidstnævnte har til formål at påkalde Guds indgriben i det jordiske liv i form af velsignelse, vejledning, helbredelse, beskyttelse eller forbandelse (Lambek 1993:110). Hvor Lambeks informanter primært bønfalder Gud på vegne af sig selv, deres slægtninge eller landsbyen, anmoder Nuriye og Yaren om Guds beskyttelse på vegne af den tyrkiske nation. Men i begge tilfælde er de bedende meget bevidste om, hvordan de kan øge bønnens kraft, eller hvad Lambek kalder dens ,illocutionary force“ og „perlocutionary persuasiveness“ (op.cit.107). For Nuriye og Yaren er bønnens kraft afhængig af både en fysisk og en følelsesmæssig indsats. Den kræver, at man kæmper sig ud af dynerne om natten, men også at man som Nuriye kan lade sig bevæge af nationens tilstand. Bønnens kraft er desuden bundet op på både kvalitet og kvantitet. På den ene side blev teheccüd-bønnen fremhævet som en særlig intens bøn, fordi man om natten er alene med Gud, mens andre sover. På den anden side afhænger bønnens styrke også af, at så mange som muligt beder samme bøn samtidig, og i dette regnskab tæller selv det ufødte barn. Men hvilken virkning forventede de to søstre af deres bønner? På hvilken måde håbede de, at bønnerne ville forandre tyrkisk politik? Selvom valgresultatet ikke faldt ud, som 
Nuriye og Yaren havde bedt for, giver deres tilgang til bøn i tiden op til valget et indblik heri.

En efterårsaften drikker Nuriye og jeg te, da Yaren kommer hjem fra arbejde på den anden side af Bosporusstrædet. Yaren fortæller, at den færge, hun sejlede hjem med, kun netop undveg et stort, men dårligt oplyst fragtskib. Færgen bremsede hårdt op, folk væltede mod hinanden, teglas splintredes. Da Yaren kiggede ud ad vinduet, så hun silhuetten af det store fragtskib glide tæt forbi i mørket. „Det var godt, jeg reciterede Cevşen imorges, selvom jeg egentlig ikke havde tid," siger Yaren med henvisning til en af de mest populære bønner blandt mine informanter. Nuriye forklarer, at de hver morgen reciterer fra Cevşen, fordi „bønnen påfører os et spirituelt beskyttelsesskjold, inden vi forlader vores hjem“. Hun smiler og tilføjer:

Er det ikke fantastisk, at Yaren var med netop den færge? Tænk på, hvor mange mennesker hun reddede. Og de andre passagere har slet ingen ide om, hvem der reddede deres liv. De aner ikke, hvem færgens superhelt var.

Nuriyes reaktion på begivenheden rejser spørgsmålet om forholdet mellem Guds almægtighed og menneskelig handlekraft, et spørgsmål, der altid har optaget både islamiske lærde (De Cillis 2014) og almindelige muslimer (Eickelman 1976; Mittermaier 2019; Menin \& Eliot 2018). For de to søstre var det udelukket at betragte begivenheden som en tilfældighed. At færgen undgik kollison, var i deres øjne resultat af guddommelig indgriben. Men Nuriyes beskrivelse af Yaren som „færgens superhelt" indikerer, at hun også tilskriver Yaren en afgørende rolle i hændelsesforløbet. Ved at prioritere bønnen den morgen og dermed påføre sig et „spirituelt beskyttelsesskjold“ fremkaldte Yaren den guddommelige indgriben, som fik færgen til at undvige. Havde jeg bedt Nuriye, der var stærk i teologi, om at uddybe, hvad hun mente med, at Yaren var færgens ,superhelt", ville hun uden tvivl have forklaret, at Yarens beslutning om at recitere Cevşen i sig selv var udslag af Guds vilje, og at gode gerninger således altid i sidste ende skal tilskrives Gud. Men det, der interesserer mig her, er, at der var visse situationer, hvor denne forbindelse mellem menneskelig handling og guddommelige prædestination blev underspillet, således at det fremstod, som om guddomenlig intervention var et resultat af menneskelig handling og ikke omvendt.

Det forhold mellem guddommelig vilje og menneskelig handling, som Nuriyes reaktion på episoden med fragtskibet frembringer, synes altså i praksis (men ikke ifølge et teologisk princip) at være karakteriseret ved, hvad Alice Elliot og Laura Menin (2018) kalder „malleable fixity“, en formulering de bruger til at beskrive forestillinger om skæbnen som noget, der både er fastlagt af Gud $o g$ formbart gennem menneskelig aktivitet. Begge forfatteres interesse i dette 
fænomen udspringer af studier af ægteskabspraksisser blandt marokkanske kvinder, men analytisk er der en subtil omend signifikant forskel på, hvordan Elliot og Menin forstår forholdet mellem Guds plan og menneskelig handlekraft. Menin beskriver den gudsgivne skæbne og hendes informanters aktive forsøg på at forme deres tilværelse som to adskilte og til tider konkurrende kræfter, der genererer en række „unresolved tensions“ (Menin 2015:906). I Elliots (2016) analyse opererer Guds almægtighed og menneskets frie vilje ikke som modsætninger, men som hinandens forudsætninger. Gennem en beskrivelse af, hvordan hendes informanter søger at tiltrække deres af Gud udkårne ægtemand, viser hun menneskeligt initiativ som nødvendigt for at aktualisere Guds plan. Med Elliots formulering skal menneskelige ,handlinger her forstås som udtryk for åbenhed og modtagelighed, snarere end de skal ses som [selvstændigt] skabende og afgørende“" (op.cit.493).

For Nuriye og Yaren artikulerede episoden med fragtskibet et lignende samspil mellem guddommelig plan og menneskelig handling: Det var aldrig Guds intention, at de to skulle kollidere, men for at undgå det krævede det, at Yaren tog ansvar og reciterede Cevşen den morgen. Man kan sige, at handlekraften var hos Gud, men at Yaren også havde et ansvar for at aktivere den. Men hvor Elliot fremhæver, at hendes informanters praksiser producerede ,åbenhed og modtagelighed" og dermed fik skæbnen til at gå i opfyldelse, understregede mange af mine Hizmet-bekendte, at også Guds plan i visse situationer var karakteriseret ved „åbenhed og modtagelighed“ overfor menneskelig praksis, primært bøn. Bøn var med andre ord ikke blot en teknik til at aktualisere skæbnen, men kunne også i visse tilfælde bearbejde og bøje skæbnen i en ønsket retning, som den følgende episode illustrerer.

Hver uge mødes jeg med en gruppe husmødre, der er aktive i Hizmet. Vi lytter til Gülens onlineprædikener, planlægger velgørenhedsarrangementer og spiser hjemmebag. Kort inden valget diskuterer kvinderne Gülens kald til bøn. Én beklager sig over, at det er svært at komme op om natten for at bede. Defne, der er respekteret for sit engagement i Hizmet, siger, at det kan være afgørende for valgets udfald, at kvinderne udfører bønnerne. For at understrege dette beretter hun om en lærer på en af Hizmets skoler, der kommer ud for en slem trafikulykke. Lægerne erklærer ham hjernedød, men hans kone skriver rundt til alle sine bekendte i bevægelsen og bønfalder dem om at bede for hendes mand. Historien spredes i bevægelsens netværk, da en Hizmet-relateret tv-kanal bringer den under overskriften „Hjælp hustru med at bede for hendes mand“. „Over hele verden beder folk for vores broder (ağabey), “4 siger Defne. Tre dage senere genvinder manden mirakuløst bevidstheden. Defne understreger historiens pointe: 
Måske havde Allah skrevet i denne mands skæbne, at hans liv skulle ende med denne trafikulykke. Men måske besluttede Allah at ændre denne persons skæbne.

Når vi virkelig beder, kan skæbnen ændres.

Her fremstår bøn altså ikke blot som en teknik til at aktualisere, men også til at påvirke Guds plan. I modsætning til de praksisser, Elliot beskriver, er bøn for mine informanter altså ikke kun „udtryk for åbenhed og modtagelighed“, men også potentielt selvstændigt ,skabende og afgørende“. Igen vil jeg understrege, at hvis man udfordrede de teologisk mere velfunderede i Hizmet på denne fremstilling, ville de sige, at sådanne udslagsgivende bønner altid allerede er produkt af Guds vilje. Men ikke desto mindre er det værd at bemærke, at der var visse afgørende situationer, hvor Guds almægtighed blev nedtonet til fordel for det individuelle ansvar. Vi har således set, hvordan bøn åbnede en mulighed for at yde indflydelse på den tyrkiske nations fremtid, ikke i modsætning til, men ved at mobilisere Guds vilje i tiden op til det vigtige nyvalg. I denne periode fremhævede mine informanter således Gud som lyttende og påvirkelig og bønnen som en metode til at gøre en forskel, ikke som et autonomt individ, men ved at „påvirke Guds hænder til at udrette ting på jorden“, som Bandak formulerer det (2017:10). Men hvad gør man så, når Gud tilsyneladende ikke efterkommer ens bønner? Det undersøger jeg i næste afsnit.

\section{At acceptere Guds plan}

Da AKP genvinder parlamentsflertallet, vækker det vrede, frygt og fortvivlelse blandt mine Hizmet-bekendte. Men det får også mange til at tvivle på styrken af deres egne bønner. En af dem er Rüya. Rüya er hjemmegående, mor til to og gift med Hakan, der umiddelbart efter valget mister sit job, fordi den Hizmetrelaterede tv-station, hvor han arbejder, må lukke. Få dage efter valget tager jeg med Rüya til møde i den gruppe af husmødre, vi besøgte i forrige afsnit. Da vi ankommer, er diskussionen om valgresultatets mulige årsager i fuld gang. En peger på stemmesnyd, en anden på regeringens skræmmekampagner og en tredje på, at mange stemte med egen økonomiske vinding for øje. Så italesætter Rüya dét, jeg ved, mange også tænker: Uanset valgresultatets „verdslige“ årsager er AKP's sejr til syvende og sidst udtryk for Guds vilje. Hvordan kunne Gud lade det ske? „Kunne det tænkes at deres [AKP's tilhængeres] bønner er stærkere end vores?“ spørger Rüya ængsteligt. „I skulle have hørt, hvordan de reciterede Al-Fatihah [Koranens første vers], inden de trådte ind i stemmeboksen, " siger en anden med henvisning til nogle naboer, der stemte på AKP. En tredje tilføjer, at umiddelbart efter valgresultatets offentliggørelse tog præsident Erdoğan til Eyüp-moskeen, et spirituelt kardinalpunkt i Istanbul, for at takke Gud for valgsejren. 
Kvindernes diskussion af valgresultatet vidner om den altgennemsyrende forvirring, der herskede blandt de fleste af mine bekendte i Hizmet i dagene umiddelbart efter valget. Man kunne således forestille sig, at valgnederlaget ville udfordre kvindernes tro på Gud som en figur, der griber direkte ind i jordiske begivenheder. En sådan reaktion er beskrevet i et ikonisk, men nu mestendels kritiseret studie af den „,kognitive dissonans“, der opstod blandt medlemmer af en apokalyptisk amerikansk kult, da det blev klart, at deres dommedagsprofeti ikke ville gå i opfyldelse (Festinger et al. 1956). Alternativt kunne man også forestille sig, at valgresultatet ville vække frygt blandt husmødrene for, at Gud havde forladt dem. I overensstemmelse med sunniislamisk tradition anså mine informanter sådan frygt som uforlignelig med tro. De understregede ofte dette med henvisning til Koranen (vers 50:16), hvori Gud bedyrer, at han til evig tid er tættere mennesket end dennes egen halspulsåre.

Men til min overraskelse afføder valgnederlaget hverken tvivl på Guds eksistens eller frygt for at være blevet forladt af Gud. Da husmødrene mødes den efterfølgende uge, er de allerede meget mere afklarede og optimistiske med hensyn til, hvordan valget skal læses. De er nu forvissede om, at valgresultatet ikke er et nederlag, men en velsignelse, fordi det giver dem muligheden for at styrke deres forhold til Gud. Kvindernes reaktion på valgresultatet kan således læses som et etnografisk eksempel på det fortløbende arbejde, det kræver at vende tvivl til tro, et tema, der i stigende grad optræder i antropologiske studier af islam (Pelkmans 2017). For kvinderne består dette arbejde af bøn. Men hvor bøn tidligere var et middel til at sikre en mere retfærdig politisk orden, er målet nu et evigt liv i paradis. Mens kvinderne forsyner sig med te og hjemmebag, udfolder følgende samtale sig:

Rüya: Vi må betragte denne tid som en prøvelse. Dem, der viser deres værd, vil tilbringe det evige liv i paradis [inşallah (med Guds vilje) svarer de andre kvinder $\mathrm{i}$ kor]. Dem, der består denne test, vil kunne træde gennem portene til paradis uden problemer [inşallah svarer de andre].

Hatice: De kan rive alt, hvad vi har bygget op, ned. De kan tage alt, hvad vi ejer fra os ... Det er en påmindelse om, at vi ikke skal knytte os for meget til jordisk gods. Alt er forgængeligt, undtagen Gud ... Endelig kan vi rette vores bønner direkte mod ham.

Selma: Som troende (mümin) må vi ikke beklage os, men spørge, hvad vi selv kan ændre ... Vi skal forbedre os, arbejde på vores mangler, styrke vores tro ... Hvad gør vi, når velsigelser (nimet) kommer til os? Vi beder til Gud. Hvad gør vi, når katastrofen (müsibet) rammer os? De, som er svage i deres tro, fortvivler ... Men den troende ved, at Allah ikke gør det her for at skade os, men for at få os til at forbedre os. Når katastrofen rammer os, beder vi. Bønnen renser hjertet for beklagelse. 
I sammenligning med kvindernes reaktion umiddelbart efter valget er denne samtale mindre famlende. Ligesom Nuriye og Defne fremhævede bøn som en afgørende metode til at forholde sig til det forestående valg, peger kvinderne i denne samtale på bønnen som central for bearbejdelsen af det uønskede valgresultatet. De bønspraksisser, mine informanter benyttede, var de samme på begge sider af valget. Udover de fem daglige bønner blev Gülens særligt ordinerede „,bønsprogram“ forlænget yderligere, dog med en lille ændring i, hvilke bønner der skulle reciteres efter den sjette natlige namaz, ligesom kvinderne blev opfordret til at finde tid til stadig mere recitation af Koranen og Cevşen. Men i det følgende vil jeg dvæle ved, hvordan samtalen mellem Rüya, Hatice og Selma frembringer en anden forståelse af bønnens kontekst, modtager og virkning end den, der dominerede $i$ tiden op til valget.

Før valget var den kontekst, mine informanter forstod deres bønner i forhold til, defineret af den nationale politiske orden. Nuriye og Yarens bønner var primært et forsøg på at ændre en politisk virkelighed, de oplevede som autoritær og uretfærdig. I samtalen mellem Rüya, Hatice og Selma hører vi, hvordan kvinderne i tiden efter valget udvider den horisont, de retter deres bønner imod, til også at inkludere livet efter døden. Formålet med deres bønner er nu ikke længere at overkomme de udfordringer, AKP-regeringens magt afføder, men at tilgå disse som en ,prøvelse“ og en „test“" hvorigennem de kan bevise, at de er værdige til paradis. Her trækker kvinderne på en forestilling om, at formålet med det jordiske liv først og fremmest er at ,indsamle point“ og ,,investere“ $\mathrm{i}$ livet efter døden, og at Gud belønner gode gerninger udført i modgang mere generøst end i medgang (jf. Hartmann 2019). Denne eskatologi var central for kvinderne, men den optrådte med større eller mindre tydelighed i forskellige situationer. Op til valget trådte den eskatologiske horisont $\mathrm{i}$ baggrunden til fordel for et mere denne-verdensligt blik på national politik, men efter valget tonede forhåbninger til paradis tydeligt frem som det perspektiv, mine informanter forstod valgets konsekvenser igennem, og den horisont, de rettede deres bønner imod.

Også modtageren af mine informanters bønner skifter karakter med det skuffende valgresultat. Den Gud, der træder frem i Selmas kommentar ovenfor, er én, der afkræver forbedring gennem prøvelse. Da vi forlader mødet, uddyber Rüya denne gudsforståelse. På mit spørgsmål om, hvorvidt hun stadig frygter, at valgresultatet viser, at Gud har vendt det døve øre til hende og Hizmet, svarer hun:

Idaclğ $l m,{ }^{5}$ sådan må vi ikke tænke. Üstad ${ }^{6}$ forklarer, at Gud aldrig afviser en bøn. Men han besvarer den, som han finder bedst. Eksempel: Du er syg, du opsøger lægen og siger, du har brug for panodil. Men lægen siger nej, det vil ikke helbrede dig, jeg udskriver penicillin. Det er dit ansvar at gå til lægen, men det er lægen, som ordinerer behandlingen. 
Ligesom Nuriye fremhæver Rüya menneskets ansvar for at bede til Gud, men nu understreger hun også den bedendes manglende evne til at foregribe, hvordan en bøn skal besvares. Hvor Gud i tiden før valget fremstod barmhjertig, lyttende og påvirkelig, er disse attributer i tiden efter valget trådt i baggrunden til fordel for en mere autoritativ og uransagelig Gud. I en artikel med titlen „The Power of God“ foreslår Samuli Schielke (2019), at antropologer burde undersøge den islamiske Guds tilsyneladende modstridende attributter ved at stille skarpt på ,de produktive spændinger og konflikter, der opstår i mødet med en Gud, der er på en gang afstraffende og barmhjertig, disciplinerende og omsorgsfuld, livgivende og dødbringende" (op.cit.3; min oversættelse). Schielke selv foreslår, at Guds flertydighed er primært produktiv, fordi den tillader en vis fleksibilitet i gudsforholdet: „Når relationen mellem Gud og mennesker skifter, påvirker det også relationer mennesker imellem, og vice versa“" (op.cit.12). Skiftet i Guds fremtoning fra før til efter valget kan læses som et eksempel på en sådan „vice versa“ situation. Mine informanters forhold til Gud skifter fra at være karakteriseret af lydhørhed til at være domineret af test, straf og belønning, i takt med at deres relationer til deres medborgere bliver tiltagende betændt og fastlåst. Havde Gud været entydigt lyttende og hjælpsom, ville det være svært at se valgresultatet som andet end et tegn på tabet af Guds gunst. Men Guds flertydighed gør, at Rüya i stedet kan se valgresultattet som en mulighed for at styrke sit gudsforhold.

Kvindernes samtale vidner desuden om en forskydning af bønnens virkning. Op til valget blev bønnen fremhævet som et middel til at forbedre en prekær politisk situation. Efter valgnederlaget var den politiske situation ikke længere et mål for forbedring i sig selv, men snarere et springbræt for, at folk i Hizmet kunne forbedre sig selv ved at styrke deres relation til Gud og deres orientering mod livet efter døden. Bønnens primære effekt var altså ikke længere lokaliseret i det ydre politiske terræn, men i Selvets indre landskab. Denne måde at forstå bøn på minder om den, Mahmood foreslår $(2001,2012)$ i sit studie af kvinder i en egyptisk fromhedsbevægelse. For Mahmoods informanter udspringer fromme følelser ikke naturligt fra subjektets indre, men skal installeres gennem praksis. Bønnen er netop en sådan selvkultiverende praksis, hvorigennem kvinderne „bevidst bearbejder ... deres intentioner, følelser og lyster i overenstemmelse med ortodokse standarter for islamisk fromhed" (Mahmood 2001:828; min oversættelse). Her er handlekraft altså ikke i første omgang evnen til at afstedkomme forandring i verden, men til at forandre sig selv. På samme måde fremhæver Selma bønnen som en teknik til at „rense hjertet" ved at vende tvivl, vrede og frygt til tillid og taknemmelighed til Gud.

Hvor bønnen tidligere udgjorde en teknik til at handle i verden ved at påkalde sig guddommelig intervention, repræsenterer den nu en form for handlekraft, hvor 
den bedende udnytter ukontrollerbar og tilsyneladende katastrofal guddommelig indgriben $i$ verden som et springbræt til at handle på sig selv. For den udenforstående kan en sådan „handling-på-Selvet“ måske forekomme som en tam erstatning for „handling-i-verden“. Men en sådan læsning overser den vigtighed, kvinderne tillægger livet efter døden. For en som Hatice var det at bede for det evige liv ikke en mindre værdig erstatning for at bede for nationens fremtid; det var tværtimod at realisere bønnens fulde potentiale. Fra et mere distanceret analytisk perspektiv er det også værd at bemærke, at selvom mine informanters bønner efter valget ikke havde politisk forandrig som formål, var de ikke uden politisk effekt. Mahmood understreger netop, at selvkultivering i kraft af den forandring, den skaber i subjektet, kan have vidtrækkende samfundsmæssige og politiske konsekvenser (Mahmood 2012:xi). I mine informanters tilfælde var bønnen som en teknik til at vende vrede, frustration og frygt til tålmodighed og taknemmelighed med til at dæmpe deres reaktion på den politiske konflikt og dermed forhindre, at de pustede yderligere til den, fx ved at fastholde anklager om valgsnyd og korruption.

Kvindernes tilgang til bøn som selvkultiverende teknik i tiden efter valget ligner således den, som jeg indledningsvis bemærkede, dominerer antropologiske studier af islamisk bøn. Men som Nuriye, Defne, Selma og de andres forskelligartede engagement i bøn viser, er selvkultivering blot én blandt flere måder, de forstår og praktiserer bøn på. Deres bønspraksis bidrager således til en løbende antropologisk samtale, der i nogen tid har peget på, at islam handler om mere end selvkultivering, og at muslimers liv handler om mere end islam. Bønnens forskellige modaliteter illustrerer netop, hvordan bestræbelser på at forbedre Selvet spiller sammen med og til tider afløses af andre former for handling, her i særdeleshed forsøg på at forandre verdens gang samt bestræbelser på at tilpasse sig begivenheder, overfor hvilke man er magtesløs. Kvindernes skiftende forhold til bøn peger således på en iboende flertydighed i deres islamiske engagement. Deres reaktion på den eskalerende politiske konflikt mellem Hizmet og AKP-regeringen viser ydermere, hvordan bønnens forskellige modalitetter henholdsvis træder i forgrunden og skubbes i baggrunden i relation til et politisk landskab under forandring. Artiklen bidrager således i særdeleshed til den del af litteraturen, der insisterer på, at muslimers liv handler om mere end islam, og at det islamiske engagement derfor kun kan forstås i relation til en bredere kontekst. I en indflydelsesrig artikel fra 2009 konceptualiserer Samuli Schielke denne kontekst - hvad han slet og ret kalder ,hverdagslivet" - som en mosaik af forskellige ,moralske registre“. Islam beskrives således som ét register, der eksistererer simultant og ofte i konkurrence med andre såsom familieforpligtigelser og karriereambitioner. Jeg er enig med Schielke i, at en analytisk opmærksomhed på den kontekst, det religiøse 
praktiseres i, er uomgængelig. Men den etnografi, jeg har præsenteret her, problematiserer samtidig beskrivelsen af denne kontekst som en moralsk mosaik, hvor islam udgør et blandt mange, klart afgrænsede og gensidigt uafhængige domæner (jf. Hirschkind 2014; Fadil \& Fernando 2015). Hvad jeg har forsøgt at skrive frem i denne artikel, er et mere dynamisk og gensidigt konstituerende forhold mellem islamisk engagement og den politiske kontekst, dette praktiseres i. Mine informanters skiftende forhold til bøn i tiden før og tiden efter det afgørende parlamentsvalg viser netop, at den måde, de forstod og handlede i den politiske konflikt på, var formet af deres forhold til islam, og at deres forhold til islam forandredes, i takt med at den politiske konflikt udviklede sig.

Afslutningsvis vil jeg vende tilbage til det spørgsmål, Nuriye ansporede mig til at stille $\mathrm{i}$ indledningen, nemlig, hvordan bønnen udgjorde et „våben“ $i$ en politisk konflikt med vidtrækkende økonomiske, sociale og eksistentielle konsekvenser.

\section{Afrunding: bønnen som „våben“}

Som Bandak og Henkel påpeger i introduktionen til dette temanummer, er forandring, opbrud og krise ofte foranledning til, at folk vender sig mod Gud i bøn. I denne artikel har jeg forsøgt at nuancere, hvordan mine bekendte i Hizmet fandt styrke i deres bønner i en tid, hvor livet, som de kendte det, var i opløsning. Artiklen viser bøn som en metode til at forstå og aktivt handle $\mathrm{i}$ en foranderlig tilværelse snarere end som en form for eskapistisk ansvarsfralæggelse. Mere specifikt peger jeg på, at for de kvinder, jeg har præsenteret, er styrken ved bønsarbejdet ikke, at det fremkalder en klart defineret og entydig islamisk forklaringsramme, men derimod, at det åbner for en række forskellige måder at handle på. I tiden før parlamentsvalget, da det stadig var et åbent spørgsmål, hvor konflikten mellem AKP og Hizmet ville lande, fremhævede kvinderne således deres individuelle ansvar og anså primært bøn som en teknik til at påkalde sig Guds indgriben og dermed som en måde, hvorpå de kunne være med til at forme deres og den tyrkiske nations fremtid på jord. Med valget, der forseglede Hizmets nederlag, skiftede mine informanters læsning af situationen. De argumenterede nu for, at konflikten var en prøvelse fra Gud, der pålagde dem at handle på deres Selv og forberede sig på livet efter døden. Det bønsarbejde, som kvinderne i denne artikel udfører, viser således en flertydighed i det religiøse engagement; at bønnen både kan have til formål at forandre verden og være en metode til at mobilisere det uforudsigelige og ukontrollable, til at forbedre Selvet. Netop fordi bønsarbejdet besidder denne flertydighed eller ,smidighed“, som Mauss formulerer det, gjorde det mine informanter i stand til hele tiden at pege på nye muligheder i en situation, der ellers syntes tiltagende håbløs og fastlåst. 
Tilbage står et spørgsmål om, hvordan kvinderne, som vi har mødt i artiklen, formår at bevæge sig mellem så fundamentalt forskellige opfattelser af konflikten, og i forlængelse heraf også af selve meningen med tilværelsen og af deres forhold til Gud, uden at det afføder nævneværdig eksistentiel forvirring, tvivl eller ambivalens. Jeg vil foreslå, at bønnen er med til at facilitere denne relativt ubesværede bevægelse. Mens mine informanters forståelse af bønnens kontekst, modtager og virkning skiftede over tid, forblev deres faktiske bønspraksis mere eller mindre uændret. Denne kontinuitet i praksis var med til at etablere en oplevelse af sammenhæng $\mathrm{i}$ en periode, hvor deres blik på verden og deres egen position heri ellers undergik drastisk forandring. For mine informanter spiller bønnen således en rolle, der minder om den, Henkel som tidligere nævnt analyserer blandt sine tyrkiske informanter i starten af 2000'erne, men med et tvist. For Henkels informanter var bønnen med til at mediere mellem forskellige muslimske grupperinger, der repræsenterede forskellige tolkninger af islam, og dermed etablere en oplevelse af fællesskab blandt den religiøst konservative del af den tyrkiske befolkning. I det Tyrkiet, som denne artikel beskriver, er dette fællesskab vendt til fjendskab. Men bønnen medierer stadig mellem forskellige læsninger af islam, dog ikke horisontalt mellem forskellige grupper, men temporalt internt i den samme gruppe. Hvor bønnen således ikke længere var i stand til at dæmme op for social fragmentering, var den stadig med til at modvirke eksistentiel splittelse. Det er netop i denne forstand, at bønnen for mine informanter udgjorde et „våben“ i konflikten. Den gjorde det muligt at skifte mellem forskellige læsninger af islam og dermed kontinuerligt pege på nye åbninger i en situation, der ellers syntes tiltagende lukket, uden at disse skift affødte eksistentiel krise.

\section{Noter}

1. Alle etnografiske citater i artiklen er oversat fra tyrkisk af forfatteren.

2. For undtagelser, se Raudvere (2003), Padwick (1961) og Stjernholm (2021).

3. AKP blev grundlagt i 2001, som afløser for Velfærdspartiet (Refah Partisi), nedlagt ved lov få år forinden. Allerede ved valget i 2002 opnåede AKP over en tredjedel af stemmerne, hvilket, blandt andet på grund af den høje spærregrænse på 10 procent, gjorde partiet i stand til at danne flertalsregering.

4. Ağabey betyder ,ældre broder“, men bruges i sufiordner også som en respektfuld form for tiltale.

5. En uformel og kærlig form for tiltale.

6. Betyder „mester“, men er her en specifik henvisning til Said Nursi (1877-1960), Gülens teologiske ledestjerne. 


\section{Litteratur}

Bandak, Andreas

2017 The Social Life of Prayers. Introduction. Religion 47(1):1-18.

https://doi.org/10.1080/0048721X.2016.1225904.

Cagaptay, Soner

2006 Islam, Secularism and Nationalism in Modern Turkey. Who Is a Turk?

London: Routledge.

De Cillis, Maria

2014 Free Will and Predestination in Islamic Thought. Theoretical Compromises in the Works of Avicenna, al-Ghazali and Ibn'Arabi. Abingdon: Routledge.

Debevec, Liza

2012 Postponing Piety in Urban Burkina Faso. Discussing Ideas on When to Start Acting as a Pious Muslim. In: L. Debevec \& Samuli Schielke (eds): Ordinary Lives and Grand Schemes. An Anthropology of Everyday Islam. Pp. 33-47.

New York: Berghahn Books.

Eickelman, Dale

1976 Moroccan Islam. Tradition and Society in a Pilgrimage Center. Austin: University of Texas Press.

Eickelman, Dale \& James Piscatori

1996 Muslim Politics. Princeton: Princeton University Press.

Elliot, Alice

2016 The Makeup of Destiny. Predestination and the Labor of Hope in a Moroccan Emigrant Town. American Ethnologist 43(3):488-99. https://doi.org/10.1111/ amet.12341.

Elliot, Alice \& Laura Menin

2018 For an Anthropology of Destiny. HAU: Journal of Ethnographic Theory 8 (1-2):

292-99. https://doi.org/10.1086/698223.

Fadil, Nadia \& Mayanthi Fernando

2015 Rediscovering the "Everyday" Muslim. Notes on an Anthropological Divide.

HAU: Journal of Ethnographic Theory 5(2):59-88. https://doi.org/10.14318/ hau5.2.005.

Festinger, Leon, Henry Riecken \& Stanley Schachter

1956 When Prophecy Fails. A Social and Psychological Study of a Modern Group That Predicted the Destruction of the World. Minnesota: University of Minnesota Press.

Göle, Nilüfer

1996 The Forbidden Modern. Civilization and Veiling. Ann Arbor: The University of Michigan Press.

Haeri, Niloofar

2013 The Private Performance of "Salat" Prayers. Repetition, Time, and Meaning. Anthropological Quarterly 86(1):5-34.

Hartmann, Ida

Serving God and the Nation. Religious Citizenship and Societal Upheaval in Contemporary Turkey. Ph.d.-afhandling. København: Institut for Antropologi, Københavns Universitet. 
Henkel, Heiko

2005 Between Belief and Unbeliefs Lies the Performance of Salat. Meaning and Efficacy of a Muslim Ritual. Journal of the Royal Anthropological Institute 11(3): 487-507. https://doi.org/10.1111/j.1467-9655.2005.00247.x.

Hirschkind, Charles

2006 The Ethical Soundscape. Cassette Sermons and Islamic Counterpublics. New York: Columbia University Press.

2014 Charles Hirschkind's Commentary on Everyday Islam Curated Collection. Curated Collections, Cultural Anthropology Online.

Jenkins, Gareth H.

2009 Between Fact and Fantasy. Turkey's Ergenekon Investigation. Singapore: The Central Asia-Caucasus Institute.

Lambek, Michael

$1993 \quad$ Knowledge and Practice in Mayotte. Local Discourses of Islam, Sorcery and Spirit Possession. Toronto: University of Toronto Press.

Mahmood, Saba

2001 Rehearsed Spontaneity and the Conventionality of Ritual. Disciplines of Şalat. American Ethnologist 28 (4):827-53. https://doi.org/10.1525/ae.2001.28.4.827.

2012 [2005] Politics of Piety, the Islamic Revival and the Feminist Subject. Princeton, NJ: Princeton University Press.

Mauss, Marcel

2003 [1909] On Prayer. W.S.F. Picekring (ed.). New York: Berghahn Books.

Menin, Laura

2015 The Impasse of Modernity. Personal Agency, Divine Destiny, and the Unpredictability of Intimate Relationships in Morocco. Journal of the Royal Anthropological Institute 21(4):892-910. https://doi.org/10.1111/1467-9655.12293.

Mittermaier, Amira

2012 Dreams from Elsewhere. Muslim Subjectivities beyond the Trope of SelfCultivation. Journal of the Royal Anthropological Institute 18(2):247-65. https://doi.org/10.1111/j.1467-9655.2012.01742.x.

2019 Giving to God. Islamic Charity in Revolutionary Times. Oakland, CA: University of California Press.

Navaro-Yashin, Yael

2002 Faces of the State. Secularism and Public Life in Turkey. Princeton: Princeton University Press.

Padwick, Constance

1961 Muslim Devotions. A Study of Prayer-Manuals in Common Use. London: Sheldon Press.

Pelkmans, Mathijs

2017 Fragile Conviction. Changing Ideological Landscapes in Urban Kyrgyzstan. Ithaca og London: Cornell University Press.

Raudvere, Catharina

2003 The Book and the Roses. Sufi Women, Visibility, and Zikir in Contemporary Istanbul. London: I.B. Tauris. 
Rytter, Mikkel

2016 By the Beard of the Prophet. Imitation, Reflection and World Transformation among Sufis in Denmark. Ethnography 17(2):229-49. https://doi.org/10.1177/ 1466138116632000 .

Schielke, Samuli

2009 Being Good in Ramadan. Ambivalence, Fragmentation, and the Moral Self in the Lives of Young Egyptians. Journal of the Royal Anthropological Institute 15(S1): S24-S40. https://doi.org/10.1111/j.1467-9655.2009.01540.x.

2019 The Power of God. Four Proposals for an Anthropological Engagement. ZMO Programmatic Texts 13 .

Simon, Gregory M.

2009 The Soul Freed of Cares? Islamic Prayer, Subjectivity, and the Contradictions of Moral Selfhood in Minangkabau, Indonesia. American Ethnologist 36(2):258-75. https://doi.org/10.1111/j.1548-1425.2009.01134.x.

Stjernholm, Simon

2021 Närmre Allah. Muslimske predikanter om privat du'a. Tidsskriftet Antropologi 84: 73-92.

Soares, Benjamin \& Filippo Osella

2009 Islam, Politics, Anthropology. Journal of the Royal Anthropological Institute 15: S1-S23. https://doi.org/10.1111/j.1467-9655.2009.01539.x.

Turam, Berna

2007 Between Islam and the State. The Politics of Engagement. Stanford: Stanford University Press.

White, Jenny

2013 Muslim Nationalism and the New Turks. Princeton: Princeton University Press.

Yavuz, M. Hakan

2003 Islamic Political Identity in Turkey. Oxford: Oxford University Press.

2013 Toward an Islamic Enlightenment. The Gülen Movement. Oxford: Oxford University Press.

2018 The Three Stages of the Gülen Movement. From Pietistic Weeping Movement to Power-Obsessed Structure. In: H. Yavuz \& B. Balci (eds): Turkey's July $15^{\text {th }}$ Coup. What Happened and Why. Pp. 20-45. Salt Lake City: University of Utah Press.

Zürcher, Erik 1998

Turkey. A Modern History. London: I.B. Tauris Publishers. 